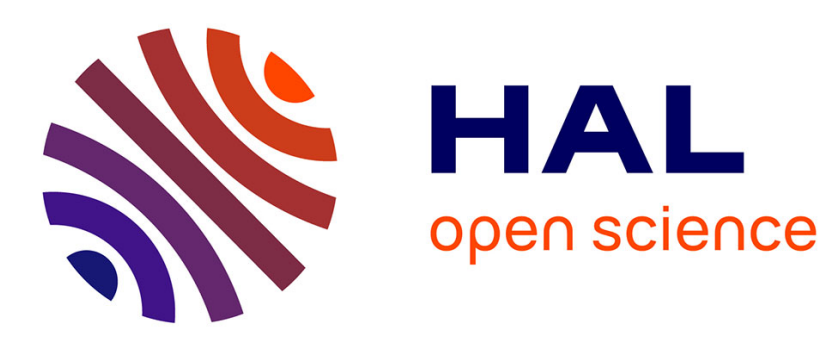

\title{
LGBT Sexuality and Families at the Start of the Twenty-First Century
}

\author{
Mignon R Moore, Michael Stambolis-Ruhstorfer
}

\section{To cite this version:}

Mignon R Moore, Michael Stambolis-Ruhstorfer. LGBT Sexuality and Families at the Start of the Twenty-First Century. Annual Review of Sociology, 2013, 39 (1), pp.491-507. 10.1146/annurev-soc071312-145643 . hal-02123638

\section{HAL Id: hal-02123638 \\ https://hal.science/hal-02123638}

Submitted on 20 Mar 2020

HAL is a multi-disciplinary open access archive for the deposit and dissemination of scientific research documents, whether they are published or not. The documents may come from teaching and research institutions in France or abroad, or from public or private research centers.
L'archive ouverte pluridisciplinaire HAL, est destinée au dépôt et à la diffusion de documents scientifiques de niveau recherche, publiés ou non, émanant des établissements d'enseignement et de recherche français ou étrangers, des laboratoires publics ou privés. 


\title{
LGBT SEXUALITIES AND FAMILIES AT THE START OF THE TWENTY-FIRST CENTURY
}

MignonR.Moore and MichaelStambolis-Ruhstorfer

Department of Sociology, University ofCalifornia, Los Angeles, California 90095; email: moore@soc.ucla.edu, mstambolis@ucla.edu

Annu.Rev. Sociol.2013.39:25.1-25.17

The Annual Review of Sociology is online at http://soc.annualreviews.org 10.1146/annurev-soc-071312-145643

\section{Keywords}

same-sex couples, lesbian and gay parenting, sexual orientation, LGBT families, transgender

\begin{abstract}
Since the start of the twenty-first century, the literature on same-sex couple relationships and families headed by single parents who identify as lesbian or gay has grown exponentially, and research published in the past 10 to 15 years tackles many new questions about sexual minority families. This review concentrates on four topics that have dominated the sociological arena: who counts as family and how/whether chang- ing definitions of family incorporate households formed by lesbian, gay, bisexual, and transgender (LGBT) people; the biological, social, and le- gal obstacles that influence family formation for this population; the outcomes for youth raised withlesbian or gay parents; and family dy- namics, relationship quality, and relationship dissolution in same-sex couple and transgender partner households. We conclude with future directions for the sociological study of LGBT sexuality and families.
\end{abstract}

\section{A NOTE ON DEFINITIONS}

In this review, we use terminology that represents the varying scope of populations in the research we review from tight to broad according to the sample and description in the cited study. Lesbian and gay refers to men and women who identify them- selves as attracted, usually exclusively, to members of the same sex/gender. As an adjective, gay may sometimes refer to both gays and lesbians. LGB (lesbian, gay, and bisexual) includes individ- uals who identify themselves as attracted to both sexes/genders. LGBT (lesbian, gay, bisexual, and transgender) includes individ- uals who have or are in the process of changing sexes or gender identities. Finally, sexual minority refers broadly to individuals whose sexualidentity/behavior is marginalized byheterosexually prescribed norms.

\section{INTRODUCTION}

Whether it is the study of the relationship be- tween sexual satisfaction and marital quality or dating and relationship patterns of young adults, sexuality has often been a component of research on families. This interest in sexual- ity often took heterosexuality for granted when studying family formation and family processes. However, the literature on same-sex couple re- lationships and families headed by single par- ents who identify as lesbian or gay has grown exponentially. Social science research published since the start of the twenty-first century tack- les many new questions about sexual minority families. Psychologists are writing about fam- ily processes, relationship quality between part- ners, and children's socioemotional outcomes and development. Sociologists have been con- sidering 
these issues while also grappling with questions regarding how these families relate to social institutions such as school and legal sys- tems and how these systems shape and are af- fected by lesbian and gay families. Sociological studies have also revealed the strategies adults in these households adopt to construct mean- ing so that they are perceived by outsiders as family. Because our space is limited, at times we incorporate the psychological research on lesbian, gay, bisexual, and transgender (LGBT) families, but we focus our review on four topics thathave dominated the sociological research: ${ }^{1}$

1. Who counts as family and how/whether changing definitions of family incorpo- rate LGBT people;

2. How lesbians and gay men come to have children — the biological, social, and legal obstacles that influence family formation for this population;

3. Outcomes for youth raised with openly gay parents; and

4. Family dynamics, relationship quality, and relationship dissolution in same- sex couple and transgender partner households.

We conclude with future directions for the soci- ological study of LGBT sexuality and families. Some caveats are necessary. First, most of the sociological research in this area focuses on same-sex couple households and not on single-parent households. Second, most of the research focuses on households in which the partners identify as lesbian or gay and not bisexual or transgender (see sidebar). Third, much of the work reviewed is US-based. An international and cross-cultural framework for the study of LGBT-parent families would be ideal, given that changes are happening around the world, in part independently and in part in- formed by one another, in how same-sex parent families are defined and understood. However, space limitations compel us to emphasize work done in the United States, though we make an effort to include research in other national contexts whenever possible. We recognize that by not including material from social systems in which same-sex marriage is more firmly institutionalized than in the United States (e.g., in Scandinavia and the Netherlands), as well as non-Western cultural contexts where sexual minority parenthood often takes place in the context of heterosexual unions while individuals also maintain a lesbian or gay iden- tity, we may lose some purchase on the trends we identify. ${ }^{2}$ Finally, much of this work has been interdisciplinary rather than purely soci- ological, so we draw from the work that most closely speaks to sociological understandings.

\footnotetext{
${ }^{1}$ Sociological issues relating to LGBT sexuality and fami- lies that are not well covered in this article but that have contributed important developments to this literature since the start of the twenty-first century include the relationships LGBT people have with their families of origin (Bennett \& Battle 2001, Oswald 2002, Acosta 2008), the continu- ously shifting state and federal legislation of same-sex mar- riage (Oswald \& Kuvalanka 2008), poly-parent families (Sheff 2010, Vaccaro 2010, Stacey 2011), and the gender socializa- tion of children raised in same-sex parentfamilies.

2 For example, Badgett's (2010) work offers a perspective on gay marriage that draws on precedents in the Nether- lands and Denmark as a template to help us think about sexual orientation equality in the United States. See also Andersson et al. (2006) on relationship dissolution in Norway and Sweden and Golombok's(2000) ongoing work on parenting in the United Kingdom and other countries. Herrera (2009) examines legislative frameworks and their impact on lesbian partnerships in Chile. Polásová's (2007) study is the first to examine lesbian and gay families in the Czech Republic. Potgieter's(2003)researchonblacklesbians in South Africa offers insights on children's experiences and parenting experiences in the particular cultural contexts of the region. For a review of non-Western research on LGBT parents and their children, see Lubbe (2013).
} 


\section{WHAT MAKES A FAMILY?}

The ideological debates on sexuality and family situate gays and lesbians at the heart of broader discussions of family politics. Bernstein \& Reimann (2001) argue that by making themselves visible as families, same-sex couple households reveal a subversive power that challenges dominant conceptions of gender. In her analysis of proand anti-gay marriage movements, Lehr (1999, p. 140) says that "gays and lesbians stand in a unique location from which to view family and from which to define a politics of family and private life" and should seek to undo marriage altogether in favor of new and creative ways of organizing their families beyond the liberal democratic discourse of the rights of couples. For Lehr, the recognition of gay marriage inadvertently supports politics that reinforce the disciplinary power of marriage in general. This perspective suggests that marriage should not bestow special legal privileges upon couples, regardless of sexual orientation. It advocates for a broader approach to thinking about what constitutes familial commitment and how it should be legally protected (see Polikoff 2008 for a similar perspective in the field of law, and Folgerø 2008 and Oswald et al. 2009 for other research on the interaction between queer theory and LGBT familyscholarship).

Other sociologists have found that even when same-sex couples want to marry and have society view their households as families, they are met with resistance. Stein's (2005) work shows the continuing ambivalence about the normalization of homosexuality and says that as a nation we remain divided over whether lesbians and gay men are the moral equivalent of heterosexuals. In Counted Out: Same-Sex Relations and Americans' Definitions of Family, Powell et al. (2010) analyze two waves of survey data, collected in 2003 and 2006, from a nation- ally representative sample of Americans about a variety of family-related topics, including their opinions about same-sex couple households. They find that a large segment of the US popu- lation is ambivalent or resistant to the inclusion of same-sex couples in their definition of family because they believe these relationships threaten the heterosexual family form and undermine traditional gender and sexuality norms (Powell et al. 2010, p. 103). ${ }^{3}$ These ideologies not only represent disapproval or discomfort around gay sexuality but also speak to broader understandings of gender and sexuality.

\section{DEFINING LESBIAN- AND GAY-PARENT FAMILIES}

Gates (2012b) provides one of the earliest analyses of the 2010 data for same-sex couple house- holds in the US Census. From 2000 to 2010 , the number of these households increased by about $80 \%$, from 358,390 to 646,464 . ${ }^{4}$ Different-sex unmarried couples increased by about $40 \%$ during this same period, whereas different-sex married couples increased by a much smaller rate of $3.7 \%$. Gates also found that in the American Community Survey data from 2011, 19\% of same-sex couples were raising children under age 18. These data suggest that currently there are approximately 125,000 same-sex couples raising nearly 220,000 children. The most recent report on LGBT parenting issued by the Williams Institute analyzes data from the Gallup Daily Tracking Survey collected from June to September 2012, the 2008-2010 General Social Survey, and the National Trans- gender Discrimination Survey. It estimates that as many as 6 million American children and adults have an LGBT parent (Gates 2013). It also finds that same-sex couples are also more likely than different-sex couples to be raising an adopted or foster child.

\footnotetext{
${ }^{3}$ Powell etal.(2010) also note that even in the short three- year period between waves of data, resistance to the idea of same-sex couples as family has weakened.

${ }^{4}$ Because the Censuscontains self-reported data, theincrease maybeprimarily due to an actual increase in the number of same-sex couple households. It likely is also due in part to changes in households' willingness to self-report as same-sex couples. Nevertheless, the 2010 figures might underestimate the number of these households if some people are reluc- tant to openly reporta same-sex relationship in the Census inventory.
} 
And these numbers reflect only those individuals who were in same-sex partnerships at the time of data collection.

Work with Census 2010 and other recent data has begun to shed new light on the geo- graphic, racial, ethnic, and class composition of same-sex couple families. Same-sex couple households with children are not evenly spread across geographic regions or socioeconomic class. Same-sex parenting is more common in the South, where more than a quarter of same- sex couples are raising children (Gates 2011b). One finding across demographic studies is the greater level of interraciality among same-sex couples compared with different-sex married couples ( Jepsen \& Jepsen 2002, Rosenfeld \& Kim 2005). Relative to Whites, childrearing among same-sex couples is higher among African Americans, Latinos, and American Indian/Alaskan Natives and lower among Asian and Pacific Islanders. Forty percent of African American same-sex couples, 28\% of Latino/a, 24\% of American Indian/Alaskan Native, 12\% of Asian and Pacific Islander, and 16\% of White couples have children under age 18 livingwith themin thehome(Gates2011b,

p. F3).

Rosenfeld's (2010) analyses of Census 2000 show that although same-sex couples have relatively high educational attainment and earnings, same-sex couples with children tend to come from the working class and are more likely to be from racial minority groups. Albelda et al. (2009) analyze data from Census 2000, the 2002 National Survey of Family Growth, and the 2003 and 2005 California Health Interview Surveys to compare poverty rates across sexual minority status. After controlling for other factors, they find that same-sex couple families are significantly more likely to be poor than are heterosexual married couple families. For example, African American same-sex couples have poverty rates that are significantly higher than both African American different-sex married couples and White same-sex couples. Children in lesbian and gay couple households have poverty rates twice those of children in heterosexual married couple households, and their families are more likely to receive government cash supports intended for low- income families. Analyses of recent Gallup data show that single LGBT adults raising children are three times more likely than comparable non-LGBT people to be living at or near poverty level (Gates 2013). Lesbian and gay couples who live in rural areas are much more likely to be low-income than are urban same-sex couples. These differences reveal race, ethnicity, and social class as mutually constitutive in the lives of sexual minority parents and theirchildren(Moore \& Brainer2013).

Of the nearly 650,000 same-sex couples counted in Census 2010,79,200 or about 12\% have at least one partner who is either not a US citizen or is a naturalized citizen, and these couples are raising more than 25,000 children (Konnoth \& Gates 2011). ${ }^{5}$ Existing immigration law has made it difficult for these families to legalize through marriage and bars couples who do not share the same home country from pursuing permanent residency as a couple in either partner's country of origin. However, in September 2012 the federal government officially changed deportation guidelines to define same-sex couples as families. Department of Homeland Security Secretary Janet Napolitano ordered Immigration and Customs Enforcement to issue written guidelines making clear that long-term same-sex partners are included in the definition of the phrase "family relation- ships" and should be considered as such when determining whether an individual should be deported (Sacchetti 2012). This change in pol- icy is a potential sign of greater complexity with respect to societal attitudes toward sexual minority families.

\section{PATHWAYS TO PARENTING}

There are four dominant ways individuals in same-sex partner households come to parent children: through a prior relationship with a different-sex partner that resulted in the birth of a child/children, through adoption, through the use of

5 The countries mostrepresented among these couples are Mexico (25\%), Canada(8\%), and the United Kingdom(6\%). 
assisted reproductive technologies, or by becoming a partner to someone who has done one or more of these things.

The framework that guides much of the quantitative research on these families is comparative and seeks to mea- sure relationship quality, parenting behaviors, and children's educational and socioemotional outcomes to two-biologicalparent households and other heterosexual family arrangements. The qualitative research on lesbian and gay family formation focuses on three areas: the construction and negotiation of family bonds, questions of identity as they relate to hetero- sexually prescribed gender norms, and the relationships these families have with their ex- tended kin and with social institutions such as schools and the law. The most common route to parenthood for lesbians and gay men is one in which a person has children through heterosexual contact before taking on a gay identity (Telingator \& Patterson 2008). However, the increasing social and political acceptance of lesbian and gay relationships over the past 20 years has created new opportunities for people to create families within the context of their unions or as single parents through donor insemination, surrogacy, and/or adoption. These intentional families, also referred to by Biblarz \& Savci (2010) as "planned families," represent a generational shift in lesbian and gay parenting. They have generated sociological interest for several reasons. First, they reflect the desire of sexual minorities to have children outside of heteronormative circumstances and, to some scholars (Dunne 2000, Stacey 2006), represent a radical shift in the meaning of parenthood and family. Second, sexual minorities, and particularly gay men, must navigate complicated and sometimes hostile institutions to have children and then raise them (Berkowitz \& Marsiglio 2007). Third, differences in gender, race, class, and region constrain and enable how such families overcomethese barriersandaccentuatethe inequalities among them. Finally, as these intentional families pursue greater legal recognition, judicial and legislative scrutiny has pushed scholars to interrogate the details of these families and, in particular, the outcomes for children raised in lesbian- and gay-parent households.

\section{Parenting as an Identity}

In the past decade, psychologists and schol- ars from other disciplines have advanced a significant portion of the research on lesbian and gay families with children, much of which is reviewed by Biblarz \& Savci (2010). Of particular interest to sociologists is how this group identifies, understands, and negotiates their identities as mother or father. Researchers have approached this question by looking at how couples divide housework, paid work, and child care, how they think about gender when parenting, and how they negotiate socialinstitutions that are particularly relevant to families with children, such as schools, child care settings, and playgrounds. Nancy Mezey's (2008) book examines differences between lesbian mothers and lesbians who do not want to become mothers in how they desire and/or experience motherhood, sometimes finding cleavages within and other times finding intersections across race and class. Sociologists are also concerned with providing new insights into the changing identity and emerging forms of kinship and family relationships for LGB people that accompany their new role as parents (Agigian 2004, Mamo 2007).

Across disciplines, the bulk of research has emphasized the experiences in lesbian house- holds with children because, compared with gay men, it is easier for women to have children through nonheterosexual reproduction, such as various forms of donor insemination (Biblarz \& Savci 2010). For example, Agigian's (2004) work looks at the legal and medical advances in lesbian insemination practices and their impact and potential for lesbian family formation. Mamo (2007) introduces the notion of affinity ties, which describe how the couple chooses a donor that has similar traits as the birth mother's partner and her family in physical appearance, national origin, religious ancestry, cultural interests, hobbies, and other social qualities. These characteristics serve as kinship devices for constructing imagined relatedness, social connection, and sociallegitimacy.

Sociological research on gay male inten- tional families is relatively small compared with that on lesbian 
households, although the past decade has seen several intensive studies of gay fatherhood, including four books that include a social science approach to their analyses of these men (Mallon 2004, Lewin 2009, Stacey 2011, Goldberg 2012). Similar to Mamo's work on lesbian mothers, Berkowitz (2007) is concerned with the meanings and understandings gay men have about father- hood as an identity. Stacey (2006) argues that gay men must confront the idea that men in general are not naturally predisposed to raising children and that gay men in particular are unfit for parenthood. Despite these symbolic challenges, as men learn about the logistics of becoming fathers they develop a "procreative consciousness" or sense of self that conjugates their identity both as fathers and as gay men (Berkowitz 2007, Berkowitz \& Marsiglio 2007). Institutional contexts and structural op- portunities are rapidly shifting how gay men become fathers, but differences in resources (e.g., institutional knowledge, access to attorneys) and uneven laws across jurisdictions create inequalities in the abilities of gay men to reproduce (Bergman et al. 2010). In the above studies, surrogacy was the least common pathway to gay male parenthood because it was often prohibitively expensive and available only in certain jurisdictions. Of those that did choose surrogacy, gay couples had to confront the issue of how, if at all, to incorporate the surrogate mother into the future life of the child and negotiate feelings around only one father's biological relatedness to the child (Berkowitz \& Marsiglio 2007).

\section{Adoption}

The adoption of children by lesbians and gay men has been a controversial issue in the United States and in many other countries, primar- ily around the capabilities of lesbian and gay adults to effectively parent and the question of whether a heterosexual mother and father are the most appropriate models for children's development and gender socialization. In the early $1980 \mathrm{~s}$, the number of children in fos- ter care increased dramatically, and the prac- tice of screening adoption applicants changed as child welfare professionals began to rethink their notions of what constituted acceptable mothers and fathers for waiting children. The concept of a so-called suitable family expanded to include single parents, grandparents, parents of different ethnicities, lower-income families, and, since the 1990s in many states, lesbians and gay men (Esposito \& Biafora 2007). Drawing from three national data sources, Gates (2013) estimates that same-sex couples are currently raising more than 25,000 adopted and fosterchildren in the United States. Same-sex cou- ples raising children are four times more likely than their different-sex counterparts to be raising an adopted child and six times more likely to be raising foster children. These figures signif- icantly underestimate LGBT parent adoption because they do not account for single-parent sexual minorities who have adopted or are fostering a child. National survey data suggest that lesbian and gay adoptive parents share several demographic characteristics with heterosexual adoptive parents. Gates's (2011b) analysis of Census 2010 showed that although racial and ethnic minority same-sex couples were signifi- cantly more likely to be raising children, White same-sex couples were significantly more likely to have used adoption to have children. Same- sex couples with adopted children have the highest average annual household income of all adoptive family types, including heterosexual married adoptive couples (Gates et al. 2007).

Shapiro (2013) writes about the ways state laws govern LGBT-parent families. She argues that the key distinction in the law for parental rights in same-sex couple households is whether one or both adults are the legal parent of the child. Once recognition as a legal parent is attained, the rights of parents do not vary based on sexual orientation, but legal differences across states and varying judge's adjudications, especially in the case of custody determinations, can create uncertainty for families. Given that in some jurisdictions only the biological parent in a gay or lesbian intentional family is automat- ically recognized as a legal guardian of the child, many parents seek out a second-parent adop- tion in which the nonbiological partner is fully recognized as an equal parent (Polikoff 2008). In a study of 40 
lesbian mothers, Hequembourg (2004) found that second-parent adoption was a powerful tool for intentional lesbian families to overcome the "incomplete institutionalization" of gay parenting and other material and sym- bolic barriers by establishing a legal tie between thenonbiological parentandherchildren.

Although second-parent adoption offers a more secure legal environment for families to raise children, it also affects custody when couples end their relationships and is not generally used in lesbian stepfamilies. Work by Gartrell and colleagues (2011) shows that second- parent adoption makes custody decisions more complicated for judges but results in a more eq- uitable sharing of time between parents than in instances when only one parent was recognized as the legal guardian. Furthermore, the likeli- hood that a child reported feeling close to both mothers was significantly higher in families that had second-parent adoptions. Evidence from the law and society literature suggests that the granting of second-parent adoption is subject to the individual appreciation of judges and is highly variable across jurisdictions, which can exaggerate inequalities among sexualminority families(S.G. Mezey 2008).

Among couples seeking to adopt children through the foster care system or through pri- vate adoption, Shapiro says the variance in state law regarding the right of same-sex couples to legally marry affects the ability of these partners to attain legal parent status. There are no states that prohibit adoption because of sexual orientation, so an openly gay man or woman can pursue this path to family formation. How- ever, some states require couples who jointly adopt to be legally married but do not permit same-sex marriage, effectively establishing a hi- erarchy in the parental relationship in which only the adopting adult has the legal tie to the child. Some states have said that secondparent adoptions are not permissible under the adoption statutes in those states for either same-sex or different-sex couples who are notmarried, which prevents same-sex couples fromadopting children.

\section{CHILDREN'S OUTCOMES IN SAME-SEX PARENT FAMILIES}

The outcomes for children raised by same- sex parents versus those of children raised by different-sex parents have garnered significant political and media attention. Some debate ex- ists about the degree to which this research either over- or understates the differences or similarities between these groups, the impact the political setting has on study results, and whether finding different outcomes for chil- dren of gays and lesbians matters. The highly politicized nature of these questions and of same-sex parent families more generally has sparked a rich and complex discussion about the relationship between research and pol- icy, methodological challenges, and the claims stakeholders make based on the literature. For instance, Marks (2012) and Regnerus (2012a) criticized the American Psychological Associ- ation's (2005) report and subsequent briefs on lesbian and gay parenting, widely used by advocates of same-sex marriage, for inaccurately representing the literature and for failing to point out data limitations. In turn, opponents of same-sex marriage used these pieces in ami- cus curiae briefs arguing in favor of upholding the1996DefenseofMarriageActcurrentlybe- fore federalcourts.

Scholarship on the outcomes for children raised in same-sex parent households primar- ily considers lesbianheaded families. Most analyses (Wainright et al. 2004; Wainright \& Patterson 2006, 2008; Rosenfeld 2010) show that years spent being raised by same-sex couple parents creates no significant disadvantage for children. Although the absence of a significant effect in some studies may be due to small sample sizes, even studies using nationally representative data (Fedewa \& Clark 2009, Rosenfeld 2010) typically do not find adisadvantage.

However, contrary findings - that children of gay parents seem to fare worse (Regnerus 2012a, Allen et al. 2013) - have used a broader set of family definitions and ill-defined causal mechanisms that treat outcomes that were al- ready present when the children lived with two different-sex parents as if they were outcomes that appeared later on after the children had spent time in a same-sex couple family (Allen et al. 2013; see Rosenfeld 2013 for an explanation). Rather than defining "children raised by gays and lesbians" as those children who grew up in intentional 
same-sex families, these studies include $(a)$ respondents who ever lived, even briefly, with a same-sex couple; $(b)$ respondents who claim at least one of their parents engaged in same-sex behavior even if that par- ent was never in a same-sex couple; and $(c)$ re- spondents whose parent took on a gay identity after a divorce or after the respondent reached adulthood (Gates 2012a; Regnerus 2012b; M.J. Rosenfeld, unpublished data). Thus, these stud- ies do not specifically examine children raised by two same-sex parents and cannot speak to the impact of same-sex parenting on children's outcomes. A recent amicus curiae brief filed by the American Sociological Association (2013) argues that because of these and othermethod- ological issues, including a failure to account for family transitions, such findings do not un- dermine the "scholarly consensus" that children raised by gay and lesbian couples face no dis- advantages. It states, "The clear and consistent consensus in the social science profession is that across a wide range of indicators, children fare just as well when they are raised by same-sex parents when compared to children raised by oppositesex parents" (p. 3).

The absence of a disadvantage for children in most of the research on same-sex parent families does not necessarily mean the absence of any differences. Some scholars have warned that, in an effort to demonstrate the fitness of lesbian and gay households to raise children, family scholars may have inadvertently over- looked the ways that children raised by gays and lesbians differ from their peers in different-sex parent households. In their reviews on parental gender and parental sexual orientation, Biblarz \& Stacey (2010) and Stacey \& Biblarz (2001), though not always able to identify the relative strength of individual studies, highlight some interesting dimensions on which same-sex par- ents behave differently than heterosexual par- ents. For instance, same-sex parents are less worried about gender nonconformity, spend more time on shared interests and activities, and use less corporal punishment. The divi- sion of labor in lesbian relationships is simulta- neously less taken for granted and more equal when compared with heterosexual relationships (Sutfin et al. 2008). Consequently, children raised in this context may grow up with a moreflexible understanding of the expectations they should have for their own gender and sexuality (Gartrell et al. 2011). Although we must use caution when attempting to generalize from re- search with small sample sizes, Gartrell et al.'s (2011) findings suggest that, among other dif- ferences in sexual orientation, behavior, and risk exposure, girls raised with lesbian parents have an older age at first heterosexual contact and hold less rigid ideas about their own sexual- ity than do girls raised by heterosexual parents. Some of the newest research in this field has begun to hypothesize about the role of fam- ily transitions in the outcomes for children in same-sex parent families. Moore (2008) noted the conflict that can occur between the biolog- ical mother and her partner over authority in lesbian stepfamilies when children have experi- enced a transition from one family type to an- other. The biological mother's greater say over childrearing decisions, combined with her in- terest in being recognized as the primary parent and other structural components of their rela- tionship, can lead to disharmony in the home that might affect relationship quality and dura- tion as well as children's well-being. In contrast, couples who had children together through as- sisted reproductive technologies want society to accept them as equal parents and tend to make parenting decisions together. Moreover, their children do not have the experience of mari- tal or relationship disruption, as do children in lesbian stepfamilies.

Rosenfeld (2010) and Potter (2012) tell us that just as family transitions and instabil- ity matter for the wellbeing of children in households with different-sex parents and sin- gle parents, they may also matter for children in same-sex parent families. For exam- ple, Potter (2012) used data from the Early Childhood Longitudinal Study-K to examine whether and how changes in family structure between kindergarten and eighth grade related to math achievement. Same-sex parent fami- lies were included as a type of family structure. He found that children who continuously lived with two same-sex parents had math assess- ment scores that were about one point higher and not significantly different from children who continuously lived with two biological par- ents. However, the number 
of cumulative fam- ily transitions a child experienced significantly reduced her or his test scores, and this was true across family status. Accounting for family in- stability through family transitions or in other ways is crucial to the question of how family structure matters for children's well-being.

\section{FAMILY DYNAMICS IN HOUSEHOLDS HEADED BY LESBIANS, GAY MEN, AND TRANSGENDER PEOPLE}

The psychological research on family process in LGBT-parent families mostly compares the in- timate relationships of same-sex and different- sex couples in relationship satisfaction, rates of dissolution, the effects of parenthood and legal recognition on these dynamics, and the po- tential effects of these things on their children. Sociologists are looking at these relationships through slightly different lenses. Oswald and colleagues (Oswald 2002, Oswald et al. 2008) examine how lesbian and gay couples negotiate their relationships with their families of origin and how the rituals around commitment ceremonies and marriage facilitate or complicate those interactions. Same-sex couples use intentionality — or strategies to legitimize and support their relationships — and redefinition — or language, culture, and symbols - to make meaning and affirm their social networks. Related to this theme is the work of Reczek et al. (2009), who show the ways couples use or do not use rituals such as commitment ceremonies to legitimate their unions and transition to a more serious state in their relationships. These findings point us to alternative forms and expressions of union making.

Sullivan (2004), Steinbugler (2012), and Moore (2011) are among those sociologists who have produced books in the past 10 years using interview and ethnographic data to study family processes in lesbian couple families. Sullivan (2004, p. 8) examines the egalitarian nature of housework in lesbian couplehouseholds and their particular efforts to "dis- rupt the power eminent in gender relations." Steinbugler (2012) considers how race debates about a postracial US society play out in the lives of interracial same-sex and different-sex couples and analyzes the links between micro- level interactions and macro-level race relations by examining strategies through which indi- viduals maintain close relationships across lines of racial stratification. Moore (2011) weaves together an intracategorical, intersectional analysis of Black lesbian identity and family for- mation. All three studies were based primarily on qualitative data, which limits their gener- alizability, but they do suggest avenues and processes that future research should explore.

\section{Relationship Dissolution}

Despite the nonrepresentative nature of data on same-sex couple relationship quality, the liter- ature across studies suggests that heterosexual and same-sex relationships function similarly but are differently exposed to risk factors associated with relationship stability. Comparing longitudinal data from married and cohabiting different-sex and cohabiting same-sex couples, Kurdek (2006) found similar couple dynamics. Predictors of relationship stability and quality for different-sex couples such as personality traits, conflict resolution, and social support also operate for same-sex couples. Using longi- tudinal relationship dynamics and satisfaction data starting with 226 heterosexual married (80 parent and 146 nonparent) couples and 133 lesbian and gay nonparent couples, Kurdek (2004) compared relationship dissolution rates across couple types. The rates were $3.1 \%$ for heterosexual parents, $18.7 \%$ for heterosexual nonparents, $19 \%$ for gay men, and $23.8 \%$ for lesbians. When controlling for age, education, income, and years lived together, the difference between lesbians and gay men was not significant. Across this research (Peplau \& Fingerhut 2007), evidence suggests that social barriers - perceived and material — such as legal institutions, children, and interdependent finances decrease the likelihood of relationship dissolution, whereas social stressors, financial difficulties, and discrimination increase it. Consequently, cohabiting same-sex couples have 
higher relationship dissolution rates than married heterosexual couples, but more data are necessary to understand differences between lesbian and gay couples.

Full access to marriage for same-sex couples may affect dissolution rates. Using demo- graphic data from Norway and Sweden for different-sex couples marrying and same-sex couples entering a legal union-same-sex marriage was not yet legal — between 1993 and 2002, Andersson et al. (2006) found that divorce risk patterns were similar across groups but that risk levels, such as having a non-native partner, were higher for same-sex couples. Using longitudinal, nationally representative data from the United States, Rosenfeld (2012) showed that marriage (in its various legal manifestations) has the same beneficial effect in extending couple longevity for same-sex couples as marriage has always had for heterosexual couples. Furthermore, controlling for marriage and couple longevity, Rosenfeld showed that gay male couples had the same stability as heterosexual couples, whereas lesbian couples were slightlymore likely to break up.

\section{Transgender Couple Households}

After a paucity of research on transgender fami- lies, recent scholarship has begun to fill this gap (Hines 2006; Schilt \& Westbrook 2009; Pfeffer 2010, 2012; Sanger 2010; Ward 2010). These sociologists investigate intimate relationships in which at least one of the partners has or is in the process of changing sexes and how that transition impacts aspects of families such as the division of household labor, relationship formation and dissolution, communication to family and outsiders, the management of self- understandings, and the negotiation of institu- tions. To date, the sociological literature has focused on transpeople in relationships with someone of a different sex, rather than with peo- ple of the same sex (i.e., transwomen partnered with lesbians). Analyzing relationships in which one per- son is transgender reveals a complex and nu- anced dynamic of sexual and gender identity that distinguishes them from lesbian, gay, or heterosexual couples (Sanger 2010). Interviews with partners of transgender individuals show that they perform a great deal of "gendered la- bor" (Ward 2010) to help their partners achieve their desired gender both during and after tran- sition. Women in relationships with transmen report doing more of the housework and emo- tional work such as nurturing their partner or managing his medical care and health advocacy (Pfeffer 2010). They justify the inequalities in the division of labor in terms of individual pref- erence and choice that allow them to create a "family myth" of gender equality and maintain a feminist identity (Pfeffer 2010).

Transgender families are uniquely situated socially and institutionally because they can subvert or maintain legal and social norms. If they are perceived by others as ordinary heterosexual couples despite their own desire to transgress, they can use "normative resis- tance" to work against this "queer invisibil- ity" by rejecting expectations of marriage and monogamy (Pfeffer 2012, p. 580). At the same time, they can also use "inventive pragmatism" to take advantage of the social and material resources of existing heteronormative struc- tures such as legal marriage and parenthood (p. 587). Scholars in this area point to the lim- its of existing categories of analysis, such as same-sex or different-sex couples, and highlight a need for new conceptual tools for studying families. They draw on a variety of theoretical approaches from the concept of "governmen- tality" (Foucault 1991) to "emotional work" (Hochschild 1979) and "doing gender" (West \& Zimmerman 1987), and suggest new ways of understanding transgender families, a group at the intersection of the medical, legal, and social institutions of sex, gender, and sexuality (Schilt \& Westbrook 2009).

\section{Confronting Stigma}

Despite the social changes for lesbian and gay couple households in recent decades, they still face obstacles in the legal system that pose barriers to their full recognition as families. In interviews with young adults raised by lesbian 
and gay parents, Robitaille \& Saint-Jacques (2009) found that youth experienced both direct and indirect forms of stigmatization. They were more likely to have been teased or belittled because they had same-sex parents. They also reported feeling stigmatized when teachers and other adults discussed same-sex marriage or homosexuality in negative ways. Most of the adult children queried by Leddy et al. (2012) felt that lesbian families face both structural and interpersonal barriers to suc- cessful integration in society. Notwithstanding these impediments, they also report receiving mostly positive responses from their peers about their families (though some reported negative or indifferent reactions). Of those who had experienced bullying because of their mothers' sexual orientation, they reported feeling hurt and angry, as well as embarrassed. Faced with such experiences, lesbian and gay families create strategies to confront stigma. In addition to communicating closely with their children and teaching them how to talk about their family structures to others, they also create dense and diverse social support networks with families, friends, and especially other lesbian and gay parents (Peplau \& Fingerhut 2007, Bos \& van Balen 2008). These relationships allow them to have both material and psychological support to counteract the negative effects of homophobia. Children of lesbian and gay parents, especially adolescents and adults, develop their own techniques of dealing with the stigma associated with their parents' sexual orientation. For example, Leddy et al. (2012) found that young adults pursued several strate- gies including keeping quiet about their lesbian parents, speaking up and educating their peers when faced with negative comments, and, to a lesser degree, directly confronting instances of homophobia or seeking out support groups. Lick et al. (2012) linked county-level indices of social climate to psychological adjustment in individuals raised by sexual minority parents.

Better outcomes were reported for childrenliving in areas that were more supportive of LGBT populations and had antidiscrimination laws to protect sexual minority populations. These findings suggest a role that public policies and laws can play in reducing the effects of stigma for youth raised inLGBT-parent families.

\section{WHAT LIES AHEAD: FUTURE RESEARCH ON LGBT-PARENT FAMILIES}

Since the start of the twenty-first century, the status of lesbian and gay families has evolved considerably. Perhaps the most noticeable shift has been in the kinds of legal battles sexual minorities face as well in the centrality of family issues, such as marriage and parenting, within the international gay rights movement. In the 1980s and 1990s, a common legal struggle for lesbians and gay men was to gain custody of their children in instances of divorce from previous heterosexual relationships. Shapiro (2013, p. 295) says that these cases still exist, but modern LGBT family law is distinguished by a different series of cases: those in which two people - most often lesbians but increasingly gay men as well — separate and disagree over the continuing care and custody of the children. In the past 10-15 years, the field has evolved, with new and advanced data sets such as Census 2010, journals like the Journal of GLBT Family Studies and Sexuality Research and Social Policy, as well as growing support for sexuality-based research in traditional sociology departments. The political and scientific are not unrelated; recent legal advances have only heightened the importance of sociological research on sexuality and families. The integral role of expert witnesses in the ongoing federal trial of California's Proposition 8 stands as an example of how empirical work in the field can directly bear on the legal status of lesbian and gay families. These elevated stakes thus make high standards in data quality and ethical research approaches even more essential.

In this context, we see the field evolving in several directions. First, there is an obvious need to produce highquality data that accu- rately describe the lives of LGBT parents and their children (Institute of Medicine 2011). To do this we must incorporate better measures of sexual orientation into survey designs. Some of the harshest critiques of the research on LGBT sexuality and families leads us to the classic inquiry, "How do we know what we know?" Durso \& Gates (2013) document the work of a group of leading social scientists to create a roadmap 
for how to construct questions on sexual orientation that provide conceptual clarity regarding the three discrete dimensions of sexuality identified by Laumann et al. (1994): sexual attraction, sexual behavior, and sexual identity. Measurement, not just of sexual orientation but of family experiences such as relationship transitions, will go a long way in improving what is known in the field, and here is where high-quality ethnographic and interview data can make a difference. More than better measurement, responsible analyses of sexual orientation data must carefully con- siderdifferences among LGBT people, as well as those who do not wish to label their sexuality (Gates 2011a).

Second, given the momentum of legal recognition of same-sex marriage in a grow- ing number of US states and internationally, we can investigate empirically the warnings by some scholars that marriage for lesbians and gay men would ultimately result in exclusions for those who fall outside of the new "gay norm" (Warner 1999, Seidman 2002, Gilreath 2011). More generally, the demographic trends sug- gest a need to learn more about the effect of marriage, adoption, and ever-changing state and federal laws affecting sexual minority pop- ulations (Oswald \& Kuvalanka 2008, Shulman et al. 2012). One way to do this is by better understanding how ongoing legal changes re- duce, create, or exacerbate inequalities among families across the lines of race, class, gender, and sexual identity. Increasing state recognition of the marriages of same-sex couples also means we must more carefully understand distinctions between marriage and other types of same-sex unions on individual and child well-being.

Third, to further the integrity and strength of research within the field, ongoing analyses of the link between research and policy on LGBT- parent families are necessary. This conversa- tion has already been initiated and examined in several forums, particularly on the issue of children's outcomes, and continues to be rele- vant. Sociology can make a unique contribution to this question by examining how research on lesbian and gay families is funded, institutional- ized, conducted, and used in the policy sphere.

Finally, we stress that more attention needs to be paid to families on the margins: families of color, working-class families, transgender families, and households whose structures are outside the couple norm (i.e., polyamorous relationships). Yet beyond increasing the volume and centrality of empirical studies dedicated to these families, we suggest that the theoretical insights of scholars already studying them be ex- panded and developed. The understandings we gain from learning about Black lesbian families or families with transgender members, for in- stance, require us to rethink how we address the intersections of race, class, gender, and sexual- ity and have ramifications for the field of family studies more broadly. By interrogating the very categories of analysis that tend to dominate re- search on lesbian and gay families, this ground- breaking work gives scholars the opportunity to push forward a rich research agenda that avoids taking themeanings offamily forgranted.

\section{DISCLOSURE STATEMENT}

The authors are not aware of any affiliations, memberships, funding, or financial holdings that might be perceived as affecting the objectivity of this review.

\section{ACKNOWLEDGMENTS}

M.R.M. received support from the University of California, Los Angeles, Resource Centers for Minority Aging/Research Center for Health Improvement of Minority Elderly under National Institutes of Health (NIH)/National Institute on Aging (NIA) Grant P30-AG021684. The content of this article does not necessarily represent the official views of the NIA or the NIH. We thank Gary Gates, Dawne Moon, Brian Powell, Michael Rosenfeld, an anonymous reviewer, and the editors for helpful comments on an earlier draft of this review. 


\section{LITERATURE CITED}

Acosta KL. 2008. Lesbianas in the borderlands: shifting identities and imagined communities. Gend. Soc.22:639-59

Agigian A. 2004. Baby Steps: How Lesbian Alternative Insemination Is Changing the World. Middletown, CT: Wesleyan Univ. Press

Albelda R, Badgett MVL, Schneebaum A, Gates GJ. 2009. Poverty in the lesbian, gay, and bisexual commu- nity. Rep., Williams Inst., Los Angeles. http://williamsinstitute.law.ucla.edu/wp-content/uploads/ Albelda-Badgett-Schneebaum-Gates-LGB-Poverty-Report-March-2009.pdf

Allen DW, Pakaluk C, Price J. 2013. Nontraditional families and childhood progress through school: a comment on Rosenfeld. Demography 50:In press

American Psychological Associtation. 2005. Lesbian and Gay Parenting. Washington, DC: Am. Psych. Assoc.http://www.apa.org/pi/lgbt/resources/parenting-full.pdf

American Sociological Association. 2013. Brief of amicus curiae submitted in Hollingsworth et al. v. Perry et al.and U.S. v. Windsor, Nos. 12-144, 12-307

Andersson G, Noack T, Seierstad A, Weedon-Fekjær H. 2006. The demographics of same-sex marriages in Norway and Sweden. Demography 43:79-98

Badgett MVL. 2010. When Gay People Get Married: What Happens When Societies Legalize Same-Sex Marriage.New York: NYU Press

Bennett M, Battle J. 2001. "We can see them but we can't hear them": LGBT members of African American families. See Bernstein \& Reimann 2001, pp. 53-67

Bergman K, Rubio RJ, Green R-J, Padrón E. 2010. Gay men who become fathers via surrogacy: the transition to parenthood. J. GLBT Fam. Stud. 6:111-41

Berkowitz D. 2007. A sociohistorical analysis of gay men's procreative consciousness. J. GLBT Fam. Stud.3:157-90

Berkowitz D, Marsiglio W. 2007. Gay men: negotiating procreative, father, and family identities. J. Marriage Fam. 69:366-81

Bernstein M, Reimann R, eds. 2001. Queer Families, Queer Politics: Challenging Culture and the State. New York: Columbia Univ. Press

Biblarz TJ, Savci E. 2010. Lesbian, gay, bisexual, and transgender families. J. Marriage Fam. 72:480-97 Biblarz TJ, Stacey J.2010. How does the gender of parents matter? J. Marriage Fam. 72:3-22

Bos HMW, van Balen F. 2008. Children in planned lesbian families: stigmatisation, psychological adjustment and protective factors. Cult. Health Sex. 10:221-36

Dunne GA. 2000. Opting into motherhood: lesbians blurring the boundaries and transforming the meaning of parenthood and kinship. Gend. Soc. 14:11-35

Durso L, Gates GJ. 2013. Best practices: collecting and analyzing data on sexual minorities. In International Handbook on the Demography of Sexuality, Vol.5, ed. AKBaumle. New York: Springer. In press

Esposito D, Biafora FA. 2007. Toward a sociology of adoption: historical deconstruction. In Handbook of Adoption: Implications for Researchers, Practitioners, and Families, ed. RA Javier, AL Baden, FA Biafora, A Camacho-Gingerich, pp. 17-31. Thousand Oaks, CA: Sage

Fedewa AL, Clark TP. 2009. Parent practices and home-school partnerships: a differential effect for children with same-sex coupled parents? J. GLBT Fam. Stud. 5:312-39

Folgerø T. 2008. Queer nuclear families? Reproducing and transgressing heteronormativity. J. Homosex.54:124- 
149

Foucault M. 1991. Governmentality. In The Foucault Effect: Studies in Governmentality: With Two Lectures by and an Interview with Michel Foucault, ed. G Burchell, C Gordon, P Miller, pp. 87-104. Chicago: Univ. Chicago Press

Gartrell N, Bos H, Goldberg N. 2011. Adolescents of the U.S. National Longitudinal Lesbian Family Study: sexual orientation, sexual behavior, and sexual riskexposure.Arch. Sex. Behav. 40:1199-209

Gates GJ. 2011a. Counting couples, counting families: recommendations for improving measurement of intimate partner relationships. Presented at Counting Couples, Counting Families Res. Conf., July 19-20, Bowling Green, OH. http://ncfmr.bgsu.edu/pdf/Counting\%20Couples/Conference\%20Papers/file98567.pdf

Gates GJ. 2011b. Family formation and raising children among same-sex couples. Nat. Counc. Fam. Relat.FF51:F2-F4

Gates GJ. 2012a. Letter to the editor and advisory editors of Social Science Research. Soc. Sci. Res. 41:1350-51 Gates GJ. 2012b. Same-sex couples in Census 2010: race and ethnicity. Rep., Williams Inst., Los Angeles. http://williamsinstitute.law.ucla.edu/wp-content/uploads/Gates-CouplesRaceEthnicityApril-2012.pdf

Gates GJ. 2013. LGBT parenting in the United States. Rep., Williams Inst., Los Angeles. http:// williamsinstitute.law.ucla.edu/wp-content/uploads/LGBT-Parenting.pdf

Gates GJ, Badgett MVL, Macomber JE, Chambers K. 2007. Adoption and foster care by gay and lesbian parents in the United States. Rep., Williams Inst. Urban Inst., Los Angeles/Washington, DC. http:// williamsinstitute.law.ucla.edu/wp-content/uploads/Gates-Badgett-Macomber-Chambers-FinalAdoption-Report-Mar-2007.pdf

Gilreath S. 2011. The End of Straight Supremacy: Realizing Gay Liberation. New York: Cambridge Univ. Press Goldberg AE. 2012. Gay Dads: Transitions to Adoptive Fatherhood. New York: NYU Press

Goldberg AE, Allen KR, eds. 2013. LGBT-Parent Families: Innovations in Research and Implications for Practice.New York: Springer

Golombok S. 2000. Parenting: What Really Counts? London: Routledge

Hequembourg AL. 2004. Unscripted motherhood: lesbian mothers negotiating incompletely institutionalized family relationships.J. Soc. Pers. Relat. 21:739-62

Herrera F. 2009. Tradition and transgression: lesbian motherhood in Chile. Sex. Res. Soc. Policy 6:35-51

Hines S. 2006. Intimate transitions: transgender practices of partnering and parenting. Sociology 40:353-71 Hochschild AR. 1979. Emotion work, feeling rules, and social structure. Am. J. Sociol. 85:551-75

Institute of Medicine. 2011. The health of lesbian, gay, bisexual, and transgender people: building a foundation for better understanding. Consens. Rep., March 31, Inst. Med. Natl. Acad., Washington, DC. http://www. iom.edu/Reports/2011/The-Health-of-Lesbian-Gay-Bisexual-and-Transgender-People.aspx

Jepsen LK, Jepsen CA. 2002. An empirical analysis of the matching patterns of same-sex and opposite-sex couples. Demography 39:435-53

Konnoth CJ, Gates GJ. 2011. Same-sex couples and immigration in the United States. Rep., Williams Inst., Los Angeles. http://williamsinstitute.law.ucla.edu/wp-content/uploads/Gates-Konnoth- BinationalReport-Nov-2011.pdf

Kurdek LA. 2004. Are gay and lesbian cohabiting couples really different from heterosexual married couples? $J$. Marriage Fam. 66:880-900 
Kurdek LA. 2006. Differences between partners from heterosexual, gay, and lesbian cohabiting couples.J. Marriage Fam. 68:509-28

Laumann EO, Gagnon JH, Michael RT, Michaels S. 1994. The Social Organization of Sexuality: Sexual Practices in the United States. Chicago: Univ. Chicago Press

Leddy A, Gartrell N, Bos H. 2012. Growing up in a lesbian family: the life experiences of the adult daughters and sons of lesbian mothers. J. GLBT Fam. Stud. 8:243-57

Lehr V. 1999. Queer Family Values. Philadelphia, PA: Temple Univ. Press

Lewin E. 2009. Gay Fatherhood: Narratives of Family and Citizenship in America. Chicago: Univ. Chicago Press Lick D, Tornello S, Riskind R, Schmidt K, Patterson CJ. 2012. Social climate for sexual minorities predictswellbeing among heterosexual offspring of lesbian and gay parents. Sex. Res. Soc. Policy 9:99-112 Lubbe C. 2013. LGBT parents and their children: non-Western research and perspectives. See Goldberg \&

Allen 2013, pp. 209-24

Mallon GP. 2004. Gay Men Choosing Parenthood. New York: Columbia Univ. Press

Mamo L. 2007. Queering Reproduction: Achieving Pregnancy in the Age of Technoscience. Durham, NC: Duke Univ. Press

Marks L. 2012. Same-sex parenting and children's outcomes: a closer examination of the American Psycho- logical Association's brief on lesbian and gay parenting. Soc. Sci. Res. 41:735-51

Mezey NJ. 2008. New Choices, New Families: How Lesbians Decide About Motherhood. Baltimore, MD: Johns Hopkins Univ. Press

Mezey SG. 2008. Gay Families and the Courts: The Quest for Equal Rights. Lanham, MD: Rowman \& Littlefield Moore MR. 2008. Gendered powerrelations among women: astudy of household decision making in Black,lesbian stepfamilies. Am. Sociol. Rev. 73:335-56

Moore MR. 2011. Invisible Families: Gay Identities, Relationships, and Motherhood Among Black Women.Los Angeles: Univ. Calif. Press

Moore MR, Brainer A. 2013. LGBT-parent families: innovations in research and implications for practice. See Goldberg \& Allen 2013, pp. 133-48

Oswald RF. 2002. Resilience within the family networks of lesbians and gay men: intentionality and redefini- tion. $J$. Marriage Fam. 64:374-83

Oswald RF, Goldberg A, Kuvalanka K, Clausell E. 2008. Structural and moral commitment among same-sex couples: relationship duration, religiosity, and parental status. J. Fam. Psychol. 22:411-19

Oswald RF, Kuvalanka KA. 2008. Same-sex couples' legal complexities. J. Fam. Issues 29:1051-66

Oswald RF, Kuvalanka KA, Blume LB, Berkowitz D. 2009. Queering "the family.” In Handbook of Feminist Family Studies, ed. SA Lloyd, ALFew, KR Allen, pp.43-55. Thousand Oaks, CA: Sage

PeplauLA,FingerhutAW.2007. The closerelationships of lesbians and gay men. Annu. Rev. Psychol. 58:405- 24

Pfeffer CA. 2010. "Women's work"? Women partners of transgender men doing housework and emotion work. J. Marriage Fam. 72:165-83

Pfeffer CA. 2012. Normative resistance and inventive pragmatism negotiating structure and agency in trans- gender families. Gend. Soc. 26:574-02

Polásková E. 2007. The Czech lesbian family study: investigating family practices. In Beyond the Pink Curtain: Everyday Life of LGBT People in Eastern Europe, ed. R Kuhar, J Takács, pp. 201-15. Ljubljana, Slov.: Peace Inst.

Polikoff N. 2008. Beyond (Straight and Gay) Marriage: Valuing All Families Under the Law. Boston, MA: Beacon 
7:135-51

Potgieter C. 2003. Black South African lesbians: discourses on motherhood and women's roles. J. Lesbian Stud.

Potter D. 2012. Same-sex parent families and children's academic achievement. J. Marriage Fam. 74:556-71 Powell B, Bolzendahl C, Geist C, Carr Steelman L. 2010. Counted Out: Same-Sex Relations and Americans'Definitions of Family. Ithaca, NY: CUP Serv.

Reczek C, Elliott S, Umberson D. 2009. Commitment without marriage: union formation among long-term same-sex couples. J. Fam. Issues 30:738-56

Regnerus M. 2012a. How different are the adult children of parents who have same-sex relationships? Findings from the New Family Structures Study. Soc. Sci. Res. 41:752-70

Regnerus M. 2012b. Parental same-sex relationships, family instability, and subsequent life outcomes for adult children: answering critics of the New Family Structures Study with additional analyses. Soc. Sci. Res. 41:1367-77

RobitailleC,Saint-Jacques M.2009. Social stigmaand the situation ofyoung peopleinlesbianand gay families.J. Homosex. 56:421-42

Rosenfeld MJ. 2010. Nontraditional families and childhood progress through school. Demography 47:755-75 Rosenfeld MJ. 2012. Couple longevity and formal unions in the era of same-sex marriage in the U.S. Presented atAnnu. Meet. Am. Sociol. Assoc., 107th, Denver

Rosenfeld MJ. 2013. Reply to Allen et al. Demography 50:In press

Rosenfeld MJ, Kim B. 2005. The independence of young adults and the rise of interracial and same-sex unions. Am. Sociol. Rev. 70:541-62

Sacchetti M. 2012. US will consider same-sex partnerships in deportations. Boston Globe, Sept. 28. http:// www.bostonglobe.com/metro/2012/09/28/obama-administration-says-will-consider-same-sexpartnerships-deportation-proceedings/shZQkY5Slx6xZy8847t0FK/story.html

SangerT.2010.Trans People's Partnerships: Towards an Ethics of Intimacy. Basingstoke,UK:Palgrave Macmillan

Schilt K, Westbrook L. 2009. Doing gender, doing heteronormativity: "gender normals," transgender people, and the social maintenance of heterosexuality. Gend. Soc. 23:440-64

Seidman S. 2002. Beyond the Closet: The Transformation of Gay and Lesbian Life. New York: Routledge Shapiro J. 2013. The law governing LGBT-parent families. See Goldberg \& Allen 2013, pp. 291-304

Sheff E. 2010. Strategies in polyamorous parenting. In Understanding Non-Monogamies, ed. M Barker, D Langdridge, pp. 169-81. London: Routledge

Shulman JL, Gotta G, Green R-J. 2012. Will marriage matter? Effects of marriage anticipated by same-sex couples. $J$. Fam. Issues 33:158-81

Stacey J. 2006. Gay parenthood and the decline of paternity as we knew it. Sexualities 9:27-55

Stacey J. 2011. Unhitched: Love, Marriage, and Family Values from West Hollywood to Western China. New York: NYU Press

Stacey J, Biblarz TJ. 2001. (How) does the sexual orientation of parents matter? Am. Sociol. Rev. 66:159-83 Stein A. 2005. Make room for daddy: anxious masculinity and emergent homophobias in neopatriarchalpolitics. Gend. Soc. 19:601-20

Steinbugler A. 2012. Beyond Loving: Intimate Racework in Lesbian, Gay, and Straight Interracial Relationship.Oxford, UK: Oxford Univ. Press

Sullivan M. 2004. The Family of Woman: Lesbian Mothers, Their Children, and the Undoing of Gender. Los Angeles: Univ. Calif. Press

Sutfin E, Fulcher M, Bowles R, Patterson CJ. 2008. How lesbian and heterosexual parents convey attitudes about gender to 
their children: the role of gendered environments. Sex Roles 58:501-13

Telingator CJ, Patterson CJ. 2008. Children and adolescents of lesbian and gay parents. J. Am. Acad. Child Adolesc. Psychiatry 47:1364-68

Vaccaro A. 2010. Toward inclusivity in family narratives: counter-stories from queer multi-parent families.J. GLBT Fam. Stud. 6:425-46

Wainright JL, Patterson CJ. 2006. Delinquency, victimization, and substance use among adolescents with female samesex parents. J. Fam. Psychol. 20:526-30

Wainright JL, Patterson CJ. 2008. Peer relations among adolescents with female same-sex parents.Dev. Psychol. 44:117-26

Wainright JL, Russell ST, Patterson CJ. 2004. Psychosocial adjustment, school outcomes, and romantic relationships of adolescents with same-sex parents. Child Dev. 75:1886-98

Ward J. 2010. Gender labor: transmen, femmes, and collective work of transgression. Sexualities 13:236-54 Warner M. 1999. Normal and normaller: beyond gay marriage. GLQ: J. Lesbian Gay Stud. 5:119-71

West C, Zimmerman DH. 1987. Doing gender. Gend. Soc. 1:125-51 